\title{
Technical Specifications for the Neutron Radiography Facility (TRIGA Mark 1 Reactor)
}

R. L. Tomlinson

J. F. Perfect

Date Published

April 1988

Prepared for the U.S. Department of Energy Assistant Secretary for Nuclear Energy

\section{0}

EsSl $\angle O d \exists S$

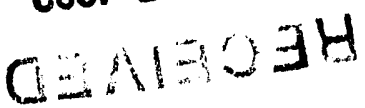

$\begin{array}{ll}\text { Westinghouse } & \text { P.O. Box } 1970 \\ \text { Hanford Company } & \text { Michland. Washington } 99352\end{array}$

Hanford Operations and Engineering Contractor for the

U.S. Defpartment of Energy under Contragt DE-AC06-87AL10930

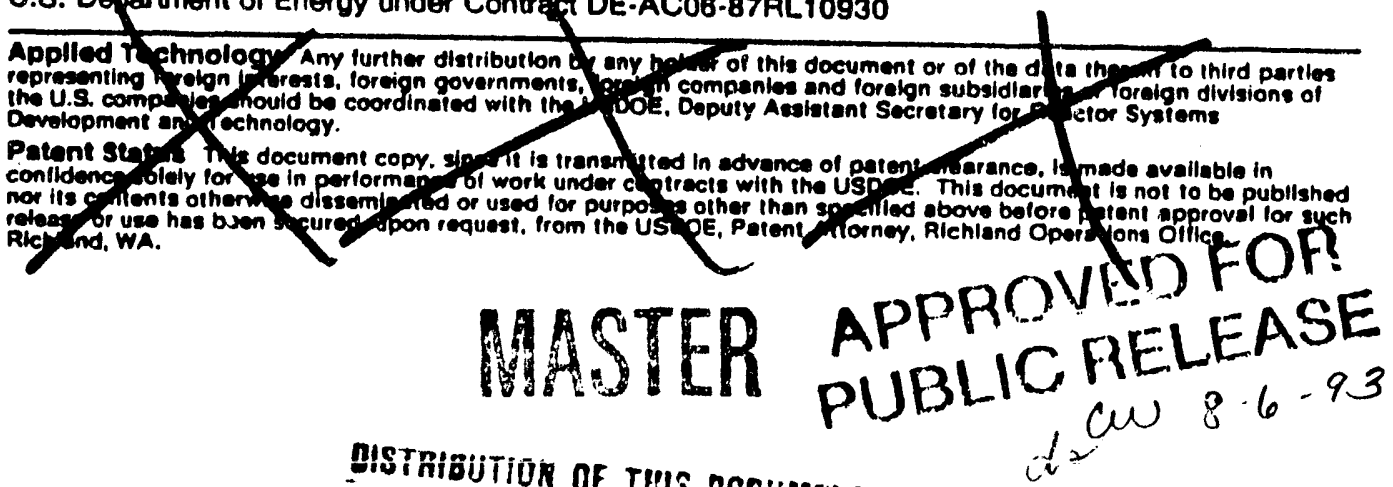




\section{DISCLAIMEA}

This report wes prepared as an sccoum of work sponsored by an segency of tha United States Governmeme Nerither the United States Governmem nor any egency thereot, nor any of their emplovees, nor any of their contractors, subcontractors or their employeca makes any warrenty. express or implied. or assumes any logal liability or responsibility for the aceuracy. completenesas or any third party's use or the resultas of such ues of any intormution. apparatus, proctuct, or procass ofeclosed. or represents that its use would not infringe privetely owned rightes Reference herein to any spocific commencial product processe or service by trade name. trademert, menufacturer, or otherwiso. does not necessarily constitute or imply its endorsememt. reco.nmendation, of favoring by the United States Government or any agency thereof or its contractors or subcontractors. The views and opinions of authors expressed herein do not necsssarihy state or reflect thoea of the United States Governmemt or am' egency thereol. 


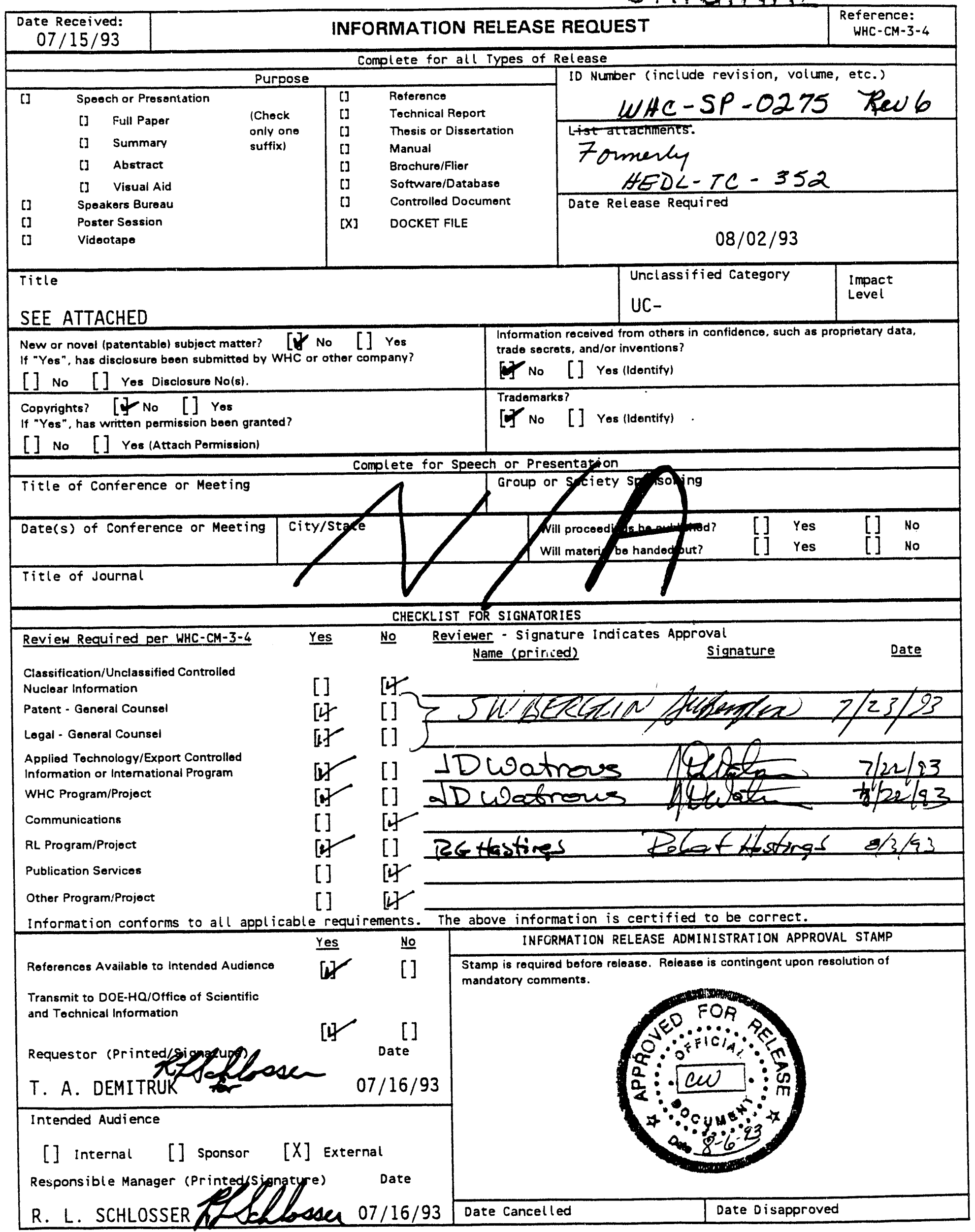




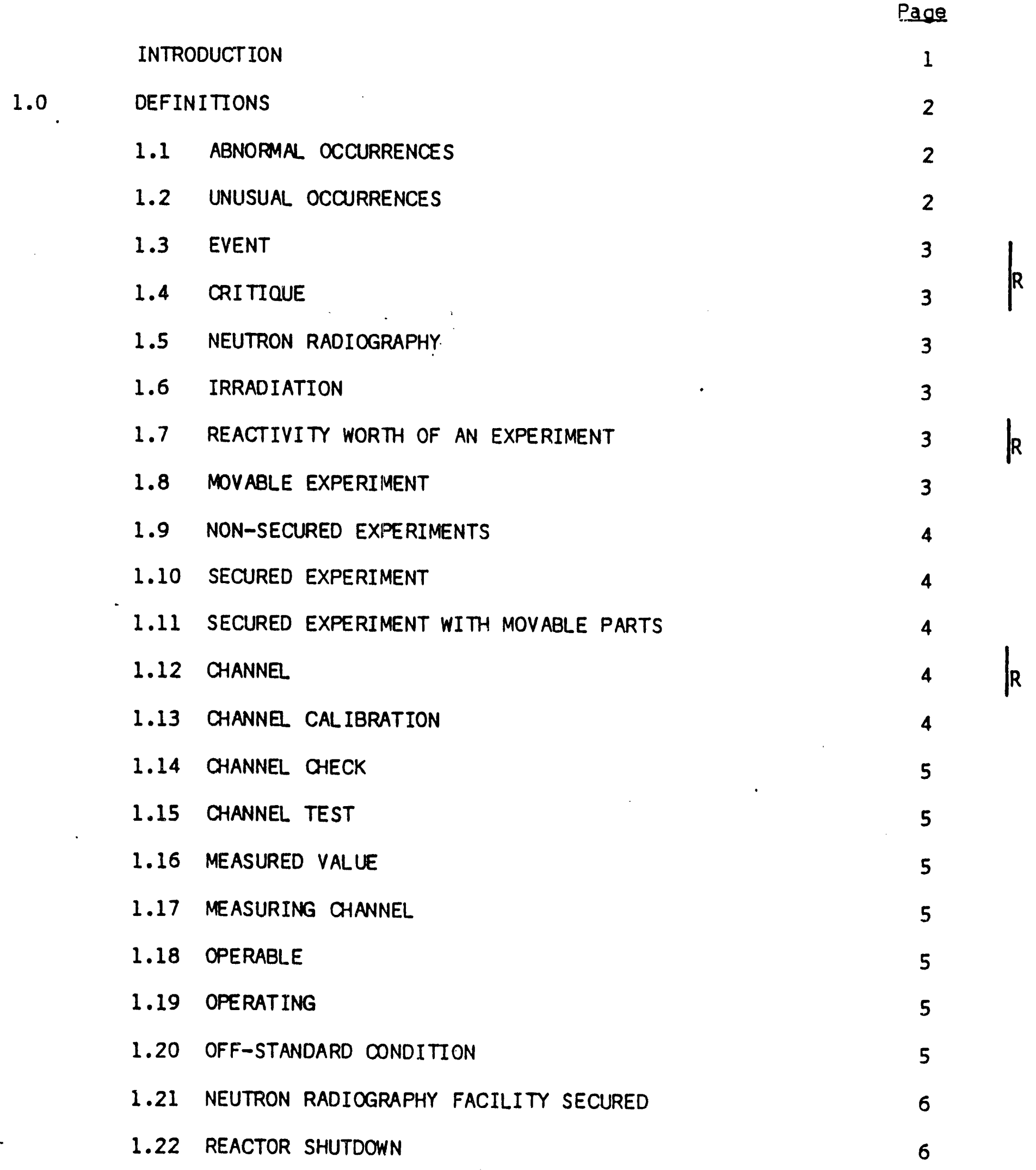




\section{CONTENTS (Cont'd)}

Page

1.23 REACTOR OPERATING 6

1.24 SHUTDOWN MARGIN 6

1.25 SCRAM

1.26 SAFETY DEVICE

1.27 SAFETY CHANNEL 7

1.28 AVAILABLE EXCESS REACTIVITY 7

1.29 OPERATING PERIOD 7

1.30 TRUE VALUE 7

1.31 REACTOR PERIOD 8

$\begin{array}{lll}1.32 & \text { ANNUAL } & 8\end{array}$

1.33 SEMIANNUAL 8

1.34 QUARTER 8

1.35 MONTH

1.36 WEEK 9

1.37 ENGINEERED SAFETY FEATURE 9

1.38 AUXILIARY SAFETY FEATURES 9

1.39 NEUTRON RADIOGRAPHY FACILITY 9

1.40 REACTOR HALL 9.

1.41 REACTOR CONTROL ROOM 10

1.42 IRRADIATED FUEL CASK HANDL ING ROOM 10

$\begin{array}{ll}1.43 & 10\end{array}$

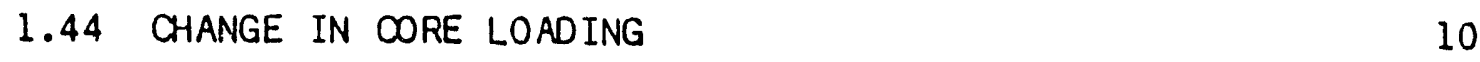

$\begin{array}{ll}1.45 \text { CHANGE IN OORE CONFIGURATION } & 10\end{array}$ 


\section{CONIENTS (Cont'd)}

Page

2.0 SAFETY LIMIT AND LIMITING SAFETY SYSTEM SETTING

11

2.1 SAFETY LIMIT

2.2 LIMITING SAFETY SYSTEM SETTING

3.0 LIMITING CONDITIONS FOR OPERATION 12

3.1 REACTIVITY LIMITATIONS 12

3.1.1 Minimum Shutdown Margin 12

3.1.2 Reactivity Insertion Rate 12

3.1.3 Core Reactivity 12

3.2 CONTROL AND SAFETY SYSTEMS 12

3.2.1 Scram Time 12

3.2.2 Measuring Channels 13

3.2.3 Safety Channeis 13

3.3 RADIATION MONITORING SYSTEMS 14

3.3.1 Routine Radiation Monitoring Systems 14

3.3.2 Radiation Monitoring Systems Required 15 for Neutron Radiography of Irradiated Fuel

3.4 ENGINEERED SAFETY FEATURE $\quad 15$

3.4.1 Reactor Hall Ventilation (HVAC) System 15

3.5 AUXILIARY SAFETY FEATURES 16

3.6 REACTOR COOLANT 17

3.7 LIMITATIONS ON EXPERIMENTS 17

3.7 .1 Reactivity Effects 17

3.7.2 Type of Experiment 18

3.7.3 Limitations of Materials in Experiments 18 


\section{CONTENTS (Cont'd)}

\section{Page}

3.7.4 Thermal-Hydraul ic Effects 19

$\begin{array}{lll}3.7 .5 & \text { Chenical Effects } & 19\end{array}$

3.7.6 Radiation Release 20

3.7.7 Experimayt Insertion and Removal 20

4.0 SURVEILLANCE REQUIREMENTS

4.1. GENERAL 21

4.2 SURVEILLANCE PERTAINING TO THE SAFETY LIMIT 21

AND LIMITING SAFETY SYSTEM SETTING

4.2.1 Linear Safety Channel Calfbration 21

4.3 SURVEILLANCE PERTAINING TO LIMITING 21 CONDITIONS FOR OPERATIONS

$\begin{array}{lll}4.3 .1 & \text { Reactivity Survelllance } & 21\end{array}$

4.3.2 Control and Safety Systems Surveillance 22

4.3.3 Radiation Monitoring Systems Surveillance 23

4.3.4 Englneered Safety Feature Surveillance 24

4.3.5 Auxiliary Safety Feature Surveillance 24

4.3.6 Coolant Conductivity Surveillance 24

4.3.7 Experiment Surveillance 24

4.3.8 Radiation Surveillance 25

4.4 MATERIAL AND EQUIPMENT CONTROLS . 25

4.4.1 Fissile Material Limitations 25

4.4.2 TRIGA Fuel Limitations 26

4.4.3 Bridge Crane Operation 26

4.4.4 Beam Stop Requirements 26 


\section{CONTENTS (Cont'd)}

5.0 DESIGN FEATURES

5.0 DESIGN FEATURES

Page

28

5.1 SITE 28

5.2 TRIGA FUEL 28

5.3 REACTOR CORE 28

5.4 CONTROL AND SAFETY SYSTEM

5.5 REACTOR HALL 29

5.6 SHIELDING 29

$\begin{array}{lll}6.0 & \text { ADMINISTRATIVE DONTROLS } & 30\end{array}$

6.1 ORGANIZATION 30

6.1.1 Management $\quad 30$

6.1.2 Facility Organization 32

6.1.3 Supporting Organization 34

6.2 AUDIT AND REVIEW

6.2.1 Audit and Reviow Organizations 35

6.3 OPERATING PROCEDURES

6.4 RECORDS AND LOGS 38

6.5 ACTION TO BE TAKEN IN THE EVENT A SAFETY 39 LIMIT IS EXCEEDED UNUSUAL OCCURRENCE ABNORMAL OCCURRENCE

6.8 REPORTING REQUIREMENTS 40

6.8.1 An Immediate Report (by Telephone) 40

6.8.2 An Event Fact Sheet Within 24 Hours · 41

6.8.3 A Written Report With in 10 Days 41

6.8.4 A Written Report Within 30 Days 41 


\section{CONTENTS (Cont'd)}

6.8.5 A Written Report Within 60 Days 42

6.8.6 A Routine Written Report Within 60 Days 42

6.9 CHANGES TO TEOHNICAL SPECIFICATIONS 43

7.0 TECHNICAL SPECIFICATION BASES 45

A2.0 SAFETY LIMIT AND LIMITING SAFETY SYSTEM SETTING

A2.1 SAFETY LIMIT $\quad 45$

A2.2 LIMITING SAFETY SYSTEM SETTING 45

'A3.1 REACTIVITY LIMITATIONS 46

A3.1.1 Minimum Shutdown Margin 46

A3.1.2 Reactivity Insertion Rate 46

A3.1.3 Core Reactivity 46

$\begin{array}{lll}\text { A3.2 CNTROL AND SAFETY SYSTEMS } & 47\end{array}$

$\begin{array}{lll}\text { A3.2.1 Scram Time } & 47\end{array}$

A3.2.2 Measuring Channels $\quad 47$

A3.2.3 Safety Channels 47

A3.3 RADIATION MONITORING SYSTEMS 48

A3.3.1 Routine Radiation Monitoring Systems 48

A3.3.2 Radiation Monitoring Systems for 49 Neutron Radiography of Irradiation Fuel

A3.4 ENGINEERED SAFETY FEATURES $\quad 49$

A3.5 AUXILIARY SAFETY FEATURES $\quad 50$

A3.6 REACTOR COOLANT 51

A3.7 LIMITATIONS ON EXPERIMENTS 51

$\begin{array}{ll}\text { A4.0 SURVEILLANCE REQUIREMENTS } & 53\end{array}$

A4.2.1 Linear Safety Channel Calibration 53

A4.3.1 Reactivity Survelliance 53

A4.3.2 Control and Safety System Surveillance 53

A4.3.3 Radiation Monitoring System 53

A4.3.4 Engineered Safety Feature Surveillance 


\section{CONTENTS (Cont'd)}

Page

A4.3.5 Auxiliary Safety Feature Surveillance 54

A4.3.6 Coolant Conductivity Surveillance 54

A4.3.7 Experiment Surveillance

54

A4.4 MATERIAL AND EQUIPMENT CONTROLS

54

A4.4.1 Fissile Material Limitations

54 


\section{EIGURES}

Figure

6.1

WHC Organization Pertinent to Neutron Radiography

Facility Operation

Page

31

R 


\section{TECHNICAL SPECIFICATIONS FOR THE \\ NEUTRON RADIOGRAPHY FACILITY \\ (TRIGA Mark I Reactor)}

\section{INIRODUCTION}

These Technical Specifications state the limits under which the Neutron Radiography Facility, with its associated TRIGA Mark I Reactor, is operated by the Westinghouse Hanford Company for the U. S. Department of Energy. These specifications cover operation of the Facility for the purpose of examination of specimens (including contained fissile material) by neutron radiography, for the irradiation of specimens in the pneumatic transfer system and approved in-core or in-pool irradiation facilities and for operator training.

The Final Safety Analysis Report (TC-344) and its supplements, and these Technical Specifications are the basic safety documents of the Neutron Radiography Facility. 
The following definitions are provided to ensure a uniform interpretation of terms and phrases used in the Technical Specifications.

\subsection{ABNORMAL OCQURRENCES}

An abnormal occurrence is any of the following:

1) Any, actual safety system setting less conservative than specified in 2.2, Limiting Safety System Setting.

2) Operation in violation of imiting Conditions for Operation (Section 3 ).

3) Incidents or conditions which prevent or could prevent the performance of the intended safety function of an engineered safety feature or the reactor safety system.

4) Release of fission products of a magnitude indicating a failure of $:$ the principal physical boundary.

5) An uncontrolled or unanticipated change in reactivity.

6) An observed inadequacy in the implementation of elther administrative or procedural controls, such that the inadequacy causes the existence or development of an unsafe condition in connection with the operation of the reactor.

7) An uncontrolled or unanticipated release of radioactivity.

\subsection{UNUSUAL OCCURRENCES}

An unusual occurrence, in addition to the examples listed in DOE Order 5000.3, related DOE/RL Supplements and WHC Management Requirements and Procedures includes Abnorma? Occurrences as defined in Section 1.1. 


\subsection{EVENT}

A significant deviation from normal operation that may or may not be reportable as an unusual occurrence or critique.

\subsection{CRITIQUE}

An eviluation of those events that WHC Management has determined requires investigation beyond that identified in the Event Fact Sheet.

\subsection{NEUTRON RADIOGRAPHY}

An operation which involves placing objects in the neutron beam at or near the collimator top for the purpose of performing nondestructive testing on those objects.

\subsection{IRRADIATION}

An irradiation is any use of the reactor to subject objects or samples to

= radiation using the pneumatic transfer system, in-pool or the $F$ ring in-core positions. This also includes use of the collimator beam for other than nondestructive testing applications.

\subsection{REACIIYITY WORTH OF AN EXPERIMENT}

The Reactivity Worth of an Experiment is the maximum absolute value of the reactivity change that would occur as a result of intended or anticipated changes or credible malfunctions that alter experiment position or configuration.

\subsection{MOYABLE EXPERIMENI}

A movable experiment is one where it is intended that the entire experiment may be moved in or near the core or into and out of the core or into and out of the reactor while the reactor is operating. 


\subsection{NON-SECURED EXPERIMENTS}

Non-secured experiments are those for which it is intended that the experiment should not move while the reactor is operating, but is held in place with less restraint than a Secured Ex.periment.

\subsection{SECURED EXPERIMENT}

A secured experiment is any experiment, experiment facility; or component of an experiment that is held in a stationary position relative to the reactor by mechanical means. The restraining forces must be substantially greater than those to which the experiment might be subjected by hydraulic, pneumatic, buoyant, or other forces which are liormal to the operating environment of the experiment, or by forces which can arise as a result of credible mal functions.

\subsection{SECURED EXPERIMENT WITH MOVABLE PARTS}

A secured experiment with movable parts is one that contains parts that are intended to be moved while the reactor is operating.

\subsection{CHANNEL}

A channel is the combination of sensor, line, amplifier, and output devices which are connected for the purpose of measuring the value of a parameter.

\subsection{CHANNEL CALIBRAIION}

A channel calibration is an adjustment of the channel such that its output corresponds with acceptable accuracy to known values of the parameter which the channel measures. Calibration shall encompass the entire channel, including equipment actuation, alarm, or trip and shall be deemed to include a Channel Test. 


\subsection{QHANNEL CHECK}

A channel check is a qualitative verification of acceptable performance by observation of channel behavior. This verification, where possible, shall include comparison of the channel with other independent channels or systems measuring the same variable.

\subsection{CHANNEL IEST}

A channel test is the introduction of a signal into the channel for verification that it is operable.

\subsection{MEASURED YALUE}

The value of a process variable as it appears on the output of a measuring channel.

\subsection{MEASURING CHANNEL}

An arrangement of sensors, signal processing equipment and output devices which act together to measure a process variable, indicate the measured value and may provide a trip or alarm signal.

\subsection{OPERABLE}

A system or component capable of performing its intended function.

\subsection{OPERATING}

A system or component performing its intended function.

\section{QEF-STANDARD CONDITION}

A condition with an operating parameter outside of the intended operating range. 
That overall state where all of the following conditions are satisfied:

1) At least 2 of the 3 neutron absorbing control rods are fully inserted or other safety devices are in shutdown position, as required by technical specifications, and

The console key switch is in the off position and the key is removed from the lock, and

2) No work is in progress involving core fuel, core structure, installed control rods, or control rod drives unless they are physicaliy decoupled from the control rods, and

3) No experiments in or near the reactor are being moved or serviced that have, on movement, a reactivity worth exceeding the maximum value allowed for a single experiment, and

4) The reactor control room and hall are locked, motion detectors and remote alarms activated.

\subsection{REACTOR SHUTDOWN}

The condition of the reactor when it is subcritical by at least the minimum shutdown margin and the magnet power key is removed and in proper custody.

\subsection{REACTOR OPERAIING}

The reactor is considered to be operating whenever it is not secured or shut down.

\subsection{SHUTDOWN MARGIN}

Shutdown margin shall mean the minimum shutdown reactivity necessary to pro$v i d e$ confidence that the reactor can be made subcritical by means of the 
control and safety systems starting from any permissible operating condition a) though the most reactive rod is in its most reactive position, and that the reactor will remain subcritical without further operator action.

\subsection{SCRAM}

The act of reducing the reactor power level by dropping all of the control rods.

\subsection{SAEETY DEYICE}

Any device in a safety channel which monitors a channel for an off-standard condition.

\subsection{SAFETY CHANNEL}

An electrical circuit which automatically and rapidiy initiates a scram or alarm when a safety device setting for detection of an off-standard condition is exceeded.

\subsection{AYAILABLE EXCESS REACTIYIIY}

Excoss reactivity is that amount of reactivity that would exist if all control rods (control, regulating, etc.) were moved to the maximum reactive condition from the point where the reactor is exactly critical $\left(k_{\text {eff }}=1\right)$.

\subsection{QPERATING PERIQD}

The planned interval between startup and shutdown checks which may include several operating modes. An operating perlod will generally be one day with numerous startups and shutdowns and different power levels but can be extended to several days of 24-hours a day operation.

\subsection{IRUE YALUE}

The actual value of a parameter. 
The time required for the reactor power level (fission density) to change by a factor of $e(-2.7)$.

\subsection{ANNUAL*}

Occurring within a 12 month period of time which can extend to a maximum of 15 months when specified as an inspection period, with the intent that such survefllance $w 11 l$ be done each year at approximately the same date each year.

\subsection{SEMIANNUAL*}

Occurring within a 6 month period of time which can extend to a maximum of 7-1/2 months when specffied as an inspection perlod, with the intent that such survelliance will be done twice each year at approximately the same date each year.

\subsection{QUARTER*}

Occurring within a 90-day period of time which can extend to a maximum of 120 days when specified as an inspection period, with the intent that such surveillance will be done once each quarter at approximately the same date each quarter.

\section{$1.35 \quad$ MONTH*}

Occurring within a 30-day period of time which can extend to a maximum of 45 days when specified as an inspection perlod, with the intent that such survelllance w 111 be done each month at approximately the same date each month.

\footnotetext{
*Extensions of nominal time periods shall not be cumulative.
} 


\subsection{WEEK*}

Occurring within a 7-day period of time which can extend to a maximurn of 10 days when specified as an inspection perlod, with the intent that such survell lance will be done within the calendar week.

\subsection{ENGINEERED SAEETY FEATURE}

Features of a unit other than reactor trips or those used only for normal operation, that are provided to prevent, limit or mitigate the release of radioactive material.

\subsection{AUXILIARY SAFETY FEATURES}

Features of a unit other than safety channels or engineered safety features, that contribute significantly to the overall safety of the reactor, operators and environment.

\subsection{NEUTRON RADIOGRAPHY FACILITY}

That portion of the 308 Building annex which houses the TRIGA reactor and associated auxiliary and neutron radiography equipment. It consists of the reactor hall and the reactor control room and the irradiated fuel cask handling room.

\subsection{REACTOR HALL}

That portion of the Neutron Radiography Facflity wherein is located the reactor, the reactor pool and associated components.

\footnotetext{
*Extensions of nominal time periods shall not be cumulative.
} 
1.41 REACTOR CONTROL ROOM

The enclosed space adjacent to the reactor hall which houses the reactor control console.

\subsection{IRRADIATED FUEL CASK HANDLING ROOM}

The room immediately adjacent to the reactor hall which contains the equipment and facilities for handling the irradiated fuel casks used when neutron radiographing, irradiated materials.

\subsection{QPERAIIONAL TEST}

A verification of the correct functioning of an instrument channel, electrical circuit or piece of equipment initiated by creating conditions identical to those experienced by the channel, circuit or equipment during its normal use.

\subsection{CHANGE IN CORE LOADING}

Increasing or decreasing the number of fuel elements or graphite reflector elements or changing the fissile content of fuel elements in the core.

\subsection{CHANGE IN CORE CONFIGURATION}

A physical change of core components specifically:

- Changing the location of fuel elements, graphite reflector elements or changing the location of any control rod.

- Modification of core, reflector, or other reactor structure which could affect core geometry. 


\subsection{SAFETY LIMIT AND LIMITING SAFETY SYSTEM SETIING}

Safety Limits are limits on important process variables which are found to be necessary to reasonably protect the integrity of the principal physical barriers which guard against the uncontrolled release of radioactivity. The principal physical barrier is the fuel cladding.

Limiting Safety System Settings (LSSSs) are those 1 imiting values for settings of the safety channels by which point protective action must be initiated. The LSSSs are chosen so that automatic protective action will terminate the abnormal situation before a safety limit. is reached.

\subsection{SAEETY LIMII}

The fuel temperature sha11 not exceed $550^{\circ} \mathrm{C}$.

\subsection{LIMIIING SAFETY SYSTEM SETIING}

The trip setpoint of any linear safety channel shall not exceed $285 \mathrm{~kW}$. The trip setpoints shall not intentionally be adjusted to greater than $275 \mathrm{~kW}$ except during operational testing of the safety channel scram features, when they may be set to a maximum of $285 \mathrm{~kW}$ for the duration of the test only [se日 section $4.3 \cdot 2.7$. 
Limiting Conditions for Operation ( $L C O$ ) are those administratively established constraints on equipment and operational characteristics which shall be adhered to during operation cf the facility.

\subsection{BEACTIVITY LIMITATIONS}

\subsubsection{Minimum Shutdown Marain}

The minimum available shutdown margin for the TRIGA Core (in a cold, xenonfree, equilibrium samarium condition) shall be $\$ 1.00(-0.72 \% \Delta k / k)$ with the control rod having the highest worth fully withdrawn. In addition, this limit must be met with all the secured, non-secured or movable experiments in the most positive reactivity state.

\subsubsection{Reactivity Insertion Rate}

The rate of positive reactivity insertion available from a control rod shall not exceed 17 cents per second $(\sim 0.12 \% \Delta k / k)$.

\subsubsection{Core Reactivity}

The core excess reactivity in a cold, xenon-, samarium-free condition shall not exceed $\$ 3.00(-2.16 \% \Delta k / k)$ with the highest worth secured, non-secured or movable experiments in the most reactive state.

\subsection{CONTRO AND SAFETY SYSTEMS}

\subsubsection{Scram Time}

The scram time for each control rod, measured from the time the off-normal signal is initiated until the control rod reaches the bottom of its travel, shall not exceed 1.5 seconds. 


\subsubsection{Measuring Channels}

The measuring channels listed below shall be in operation when the reactor is operating:

\section{Channel}

Log Power Channel

Multirange Linear

Power Channel

Linear Safety

Channel "l

Linear Safety

Channel \#2

Perlod Channel

$\frac{\text { Range }}{10^{-8}-110 \%}$
$(0$ of $250 \mathrm{~kW}$ )
$0.01 \mathrm{~W}$ (approx)
to $300 \mathrm{~kW}$
$0-110 \%$ (of
$250 \mathrm{~kW}$ )
$0-110 \%$ (of
$250 \mathrm{~kW}$ )
$-30 \mathrm{sec}$ to
$+3 \mathrm{sec}$

\section{Function}

Indicate reactor power over full range.

Indicate and record reactor power.

Indicate reactor power (in upper 2 decades.)

Indicate reactor power (in upper 2 decades.)

Indicate reactor period.

\subsubsection{Safety Channels}

The safety channels listed below shall be in operation when the reactor is operating:

\section{Channel}

Linear Safety

Channel \#1

Linear Safety

Channel \#2

Period Channel

Pool Water Temperature

Fission Chamber High

Voltage Monitor
Function

Scram at $275 \pm 10 \mathrm{~kW}$

Scram at $275 \pm 10 \mathrm{~kW}$

Alarms when the rising perlod is less than three seconds.

Alarms at $45^{\circ} \mathrm{C}$ or more.

Alarms if high voltage to a neutron detector drops below $90 \%$ of normal. 


\subsection{RADIATION MONITORING SYSTEMS}

\subsubsection{Routine Radiation Monitoring System}

The radiation monitoring equipment listed below shall be in operation when the reactor is operating:

\section{Feature}

Area Radiation Monitorl

Air Particulate Monitor ${ }^{2}$ (a)pha)

Air Particulate Monitor ${ }^{2}$ (beta-gamma)

Stack exhaust particulate and Iodine sample stations
Eunction

Monitor gamma radiation level in reactor hall.

Monitor reactor hall for airborne alpha (particulate) activity and record continuously.

Monitor for alrborne beta-gamma (particulate) activity and record continuousiy.

Provides for measurement of effluent air from the reactor hall both before and after the HEPA filters.

1 An inoperable Area Radiation monitor must be replaced with a continuous area radiation monitor within 15 minutes or the reactor must be shutdown.

2 Reactor operation may continue to the end of the operating period with one or more of these systems out of service provided surveys or samples are taken hourly using instruments which have sensitivity and accuracy comparable to the installed systems. 


\subsubsection{Radiation Monitoring Systems Required for Neutron Radiography of Irradiated Fuel}

The radiation monitoring equipment listed below shall be in operation when performing neutron radiography of irradiated fuel

Feature

High Range Radiation Monitor*

\section{Function and Alarm Setooints}

Monitors gamma radiation level within concrete shielded beam stop. Alarm set at $3 \mathrm{R} / \mathrm{hr}$ or less. Interlock prevents opening of rolling concrete shield door or movement of cask cart when dose rates $\geq 3 \mathrm{R} / \mathrm{hr}$ exist in the beam stop.

* May be bypassed only with the specific written authorization of the Managers of 300/400 Area Facilities Nuclear Safety. 300/400 Area Operational Health Physics, and Facility Operations and Administration, and then only for repalr, replacement or calibration of the channels due to mal function.

\subsection{ENGINEERED SAFETY FEATURE}

\subsubsection{Reactor $\mathrm{Hall}$ Ventilation (HYAC) System}

The reactor hall ventilation system shall fulf 111 the following requirements whenever the reactor is operating, or whenever fuel or other radioactive materials are being handled:

1) The air of the reactor hall shall be maintainec at a pressure below atmospheric. An alarm shall sound in the reactor control room if pressure $r$ ises above the negative setpoint. The nominal alarm setpoint is -0.15 "wg relative to atmosphere.

2) All air exhausted from the reactor hall shall pass through two High Efficiency Particulate Air (HEPA) filters $199.95 \%$ minimum efficiency each) placed in series. 
The following auxiliary safety features shall be operable when the reactor is operating:

\section{Feature}

Magnet Power Key Lock

Control Rod Pushbutton Interlock

Shielding Door and Cask Cart interlocks
Function

Prevents energizing the control rod magnets without the proper key. Removal of the key will initiate a scram.

Prevents more than one control rod from being withd.awn at the same time.

(a) De-energizes all control rod magnets if shielding door is not fully closed. I

(b) Prevents cask cart form being moved when the shield door is not fully closed. 1

(c) Prevents shield door form opening when high range monitor insjide beam stop is in alarm condition. 2

(d) Provents cask cart moveinent when high range radiation monitor inside beam stop is in alarm condition. 2

ihay be bypassed during maintenance. calibration and test procedures approved in writing by the Managers of $300 / 400$ Area Facilities Nuclear Sefety, 300/400 Area Operational Health Physics, and Facility Operaíons and Administration.

2 May be bypassed only with the specific-irritten authorization of the ilanagers of 300/400 Area Facilities Nuclear Safety, 300/400 Area Operational Health Physics, and Facility Operations and Administration, and then only for repair, replacement or calibration of the channels due to mal function. 
Feature

Reactor Pool Level Monitor

Rod Withdrawal Prohibit*

(Log Power Channel)

Manual Scram Bar

Loss of Console Power

Remote Scram Swftch

\section{Function}

Alarms when the pool level is outside the range of 15 to 21 inches below the floor level.

Prevents startup with less than $4 \times 10^{-9} \%$ power indicated.

De-energizes all control rod magnets.

De-energizes all control rod magnets.

Permits shutting down the reactor from a remote location.

* May be bypassed during maintenance, callibration and test procedures approved in writing by the Managers of 300/400 Area Facllities Nuclear Safety, 300/400 Area Operational Health Physics, and Facllity Operations and Administration.

\section{$3.6 \quad$ REACTOR OOLANT}

The reactor shall not be operated unless coolant conductivity can be ma intained below five micromhos/cm (averaged over a four-week perlod).

\subsection{LIMITATIONS ON EXPERIMENTS}

\subsubsection{Reactivity Effects}

1) Movable parts of secured experiments shall be 1 imited in reactivity insertion rate to less than 17 cents/sec unless their total reactivity worth is less than 5 cents for these movable parts, e.g. rabblt capsules for the pneumatic transfer facility.

2) The maximum allowed reactivity worth of any independent experiment must be less than 25 cents.

3) The total reactivity worth of all experiments must be less than 25 cents. 
Only authorized experiments defined in Section 1, are to be performed, e.g., neutron radiography, and irradiation using the pneumatic transfer facility, f-ring in-core capsules, wet or dry tubes, and in-pool irradiation experiments.

\subsubsection{Limitatien of Materials in Experiments}

1) Explosive materials such as gun powder, TNT, nitroglycerin, PETN, and corrosive materials shall not be irradiated nor radiographed.

2) Irradiation of fisslle materials shall be in accordance with an approved Experiment Proposal; taking into consideration the method of encapsulation, reactivity effects, number of fissions, power generation resulting in heat and pressure, and resultant fission product inventory.

3) Materials which can off-gas, sublime, are volatile, or produce aerosols must be so indicated on an Experiment Proposal Form, and include an analysis to provide assurance that the irradiation can be performed safely.

4) Irradiation of fissionable samples shall be limited to 0.1 gram in the fissionable isotopes per capsule with a total of 4.0 grams total in the reactor in experimental facilities.

5) Radiation levels assoclated with samples removed from the experimental faclities shall follow the as low as reasonably achlevable (ALARA) policy.

6) All dispersible samples for irradiation shall have double encapsulation. Nondispersible samples shall have at least single encapsulation. Fissionable samples shall be contained in leakproof metal encapsulation. 
7) Heat generation rate per irradiation of an individual capsule shall not exceed 30 watts.

8) Dummy Irradiation Capsule pressure shall not exceed a calculated value of $30 \mathrm{psl}$. The capsules shall be designed to withstand an internal pressure of 50 psi.

9) The total calculated inventory of irradiated materials in the facllity for neutron radiography shall be restricted to material having a total fission product content of less than $5 \times 10^{4}$ curies and 120 watts of heat.

10) Irradiated materials accepted for neutron radlography shall be contained in at least one sealed, hellum leak tested metal contalnment vesse1.

11) The maximum exposure rate measured with the instrument in contact with the surface of the cask used for transport of materlals to be neutron radiographed shall not exceed $100 \mathrm{mR} / \mathrm{hr}$.

\subsubsection{Thermal-Hydraulic Ef fects}

No experiment shall be designed such that Juring normal operation or failure, the parameters of the core could exceed the Safety Limit.

\subsubsection{Chemical Effects}

Sample encapsulation must be adequate to contain the sample material during normal or fallure conditions to prevent contamination of the reactor pool 
water or experiment apparatus. This is accomplished by double containment of the sample. A minimum purge rate of $200 \mathrm{ml} / \mathrm{m} / \mathrm{n}$ (STP) shall be provided for irradiation of nylon and polyethylene capsules exposed to integrated doses in excess of $10^{8}$ rads in open ended irradiation tubes.

\subsubsection{Radiation Release}

Proposed experiments are to be analyzed for potential radioactive effluent release and he designed to prevent or mitigate release. If any uncontrolled release of radioactivity takes place, significant enough to actuate air particulate alarms the experiment shall be terminated.

\subsubsection{Experiment Insertion and Removal}

A11 samples will be inserted and removed from the reactor with the reactor shutdown except that samples worth less than 5 cents may be inserted and removed using the pneumatic transfer tube during reactor operation. 


\subsection{SURVEILLANCE REQUIREMENTS}

\subsection{GENERAL}

These specifications apply to the surveillance of components and systems which are essential to safety of the reactor and the facility. The purposes of these specifications are to assure that: (1) the instruments, safety trips and interlocks function as designed; (2) the control rod reactivity worths and core excess are within the limits required in the safety analysis; and (3) the structural integrity of the core elements is maintained. These survellilance tests may be deferred during periods when the reactor is shutdown (except as noted) providing they are performed prior to startup. Administrative controls on material and equipment listed in Section 4.4 are to be in effect at all times.

\subsection{SURVE ILLANCE PERTAINING TO THE SAFETY LIMIT AND LIMITING SAFETY SYSTEM SETIING}

\subsubsection{Linear Safety Channel Calibration}

The two linear safety channels shall be calibrated by adjustment after comparison with the multirange linear power channel calibration annually and after each change in core configuration or detector position. A channel test of the two flux measuring safety channels shall be performed prior to each operating period.

\subsection{SURYEILLANCE PERTAINING TO LIMITING ONDITIONS FOR OPERATIONS}

\subsubsection{Reactivity Survelliance}

1) The reactivity worth and reactivity insertion rate of each control rod shall be measured and the shutdown margin computed:

\footnotetext{
- Annualiy

- Following any change in core loading or configuration.
} 
- Whenever a control rod is moved to a new core position.

NOTE: Following replacement of, modification or repair to an individual control rod, rod drive mechanism or rod control circuit only perform reactivity worth determination and reactivity insertion rate measurement on that particular control rod. The shutdown margin shall be computed utilizing this new data.

2) The core excess reactivity shall be measured:

- At the beginning of each operating period.

- Following any change in the core loading or configuration, or replacement of any fuel elements.

- For determination of the amount of reactivity worth of an experiment.

3) The reactivity worth of an experiment shall be estimated and measured before operation with said experiment at full power. The reactivity worth must be within 1 imits as stated in Section 3.7 , Limitations on Experiments. Note: Experiment reactivity worth measurements shall be performed at a low reactor power level, less than $1 \mathrm{~kW}$.

\subsubsection{Control and Safety Systems Suryeillance}

1) The scram insertion time of each control rod shall be measured annually. Scram insertion time shall also be measured whenever a rod is moved to a new core position or after any ma intenance, modification or repalr is performed on the control rod, its drive mechanism or control circuit.

2) An operational test of the manual scram bar and a channel test of the period alarm shall be performed prior to each operating period. 
3) A channel check of the linear safety channels, the log power channel, the period channel, and the multirange linear power channel and the pool water temperature channel shall be performed during the first ascent to the operating power level planned for any operating period.

4) The rod withdrawal prohibit interlock shall be operationally tested at least monthly.

5) The fission chamber high voltage monitor shall be operationally tested semiannualiy.

6) The pool water temperature instrument shall be calibrated and operationally tested semiannually.

7) The scram function of each of the two linear safety channels shall be operationaliy tested annually by increasing reactor power to the trip point. Reactor power shall not exceed $285 \mathrm{~kW}$ for this test.

8) The multirange linear power channel shall be calibrated by calorimetric means and the other power channels adfusted to agree with the 1 inear channel annually and after any change in core loading or configuration or detector position.

9) Each control rod shall be visually inspected annually for inflcation of significant distortion or deterioration.

\subsubsection{Radiation Monitoring Systems Survelllance}

Each installed radiation monitoring instrument shall be checked dafly during operation, and shall be source checked at least monthly. They w11l be callbrated annually and the alarm function operationally tested semiannually whether or not the reactor is operated. Stack exhaust. filter samples shail be changed at a minimum once every two weeks. 


\subsubsection{Engineered Safety Feature Surveillance}

The HVAC pressure control system shall be checked at least monthly. Its pressure-alarm function shall be operationally tested semi-annually. The HEPA exhaust filters shall be tested annually. All tests shall be performed whether or not the reactor is operated.

\subsubsection{Auxiliary Safety Feature Surveillance}

Each of the features 1 isted in Section 3.5 shall be operationally tested semiannually. The reactor pool level monitor shall be operationally tested quarterly whether or not the reactor is operated.

\subsubsection{Coolant Conductivity Surveillance}

Coolant conductivity shall be: .

1) Measured and recorded at the start of each operating period, and at least weekly if the reactor is not operating.

2) Averaged at least weekly over the preceding four-week period to determine compliance with the limit.

\subsubsection{Experiment Surveillance}

1) A new experiment shall not be installed in the reactor or conducted, until a hazards analysis and/or Experiment Proposal review (as per Section VI of HEDL MG-93, HEDL NRF Organization and Admin1stration manual) has been completed. Experiment review must include compliance with the limits as set forth in Section 3.7, Limitations on Experiments, of these technical specifications. A1 1 new experiments must be approved by the Manager, Facility Operations and Administration. 
2) If a particular experiment is the same as one previously conducted or is declared similar by the Reactor Operations Supervisor in regards to hazards analysis previously reviewed, the experiment may be performed after completion and approval of an Irradiation Request (as per Section VI of HEDL MG-93, HEDL NRF Organization and Administration Manual).

\subsubsection{Radiation Survelllance}

1) A Radiation Protection Technologist shall be present during all sample insertion and removal operations.

2) Generalized operational procedures shall be developed to cover the insertion and removal of experiments.

3) Radiation Work Procedures (RWP) shall be developed for the insertion, retrieval and storage of samples.

\subsection{MATERIAL AND EOUIPMENT CONTROLS}

The following administrative controls will apply to specific equipment and materials located in the Neutron Radiography Facility:

\subsubsection{Fissile Material Limitations}

TRIGA fuel elements shall be stored in standard TRIGA fuel storage racks suspended in the reactor pool. Oriver and test fuel pins shall be stored and handled in the NRF outside the reactor pool in batches not exceeding $45 \%$ of the minimum critical number. The number of fueled assemblies, containing up to 217 fuel pins, permitted in the NRF at one time shall not exceed one. The edge-to-edge spacing between batches and between the fueled section of an assembly and a batch shall be at least two feet. A fisstonable material batch not in pin form shall be limited to a total of elther $45 \%$ of the minimum critical mass or $45 \%$ of the minimum critical number. Storage and handling of fissionable material in the NRF shall be governed by approved Criticality Safety Specifications. 


\subsubsection{IRIGA Fuel Limitations}

All fuel elements in use will be inspected once every two years. Elements found to exceed the following limits shall not be used in the core.

1) Maximum transverse bow - 1/16 inch.

2) Maximum longitudinal growth - 1/10 inch.

3) Significant changes as observed by visual inspection.

4) If 10 percent or more of a core loading exceed efther the maximum bow or longitudinal growth, the entire core loading shall be inspected.

\subsubsection{Bridge Crane Operation}

1) The bridge crane shall be in the parked position and placed out of service, using the 308 Bullding tagging procedure, whenever the reactor is operating or there is a loaded fuel pin cart in the reactor hall.

2) All lifts of heavy objects using the bridge crane shall be planned and supervised by the Reactor Operations Supervisor.

3) Blocks shall not be raised higher than is necessary for safe placement and removal (approximately 3 inches above another block).

\subsubsection{Beam Stop Requirements}

1) The reactor shall not be operated unless the beam stop shielding is fully assembled and in place except for certain approved ma intenance procedures. Any reactor operation for maintenance shall 
then be at $<1 \mathrm{~kW}$ reactor power. A Radiation Protection Technologist is required to be present to perform radiation surveys of the reactor hall during this reactor operation.

2) The rotating shield of an irradiated fuel cask containing irradiated fuel shall not be opened to the beam stop shielding unless the concrete shlelding door is fully closed. 


\subsection{DESIGN FEATURES}

$5.1 \quad$ SITE

The reactor hall is an annex to the 308 Bullding located in the 300 Area of the DOE Hanford Reservation near Richland, Washington. The 308 Building is in a fenced enclosure with controlled access to the bullding and reactor hall.

\subsection{IRIGA FUEL}

Both stainless steel and aluminum-clad TRIGA fuel elements are authorized for the reactor core loading.

The fuel element uranium is enriched to $20 \%$ uranfum-235 with the following characteristics:

1) Stainless Steel - High hydride fuel (U- $\left.\mathrm{ZrH}_{1.5}\right)$ with $8.5 \%$ uranium by weight, 1.47-inch outside diameter, 0.02-inch wall thickness, and a 15-inch fuel column.

2) Aluminum - Low hydride fuel $\left(U-\mathrm{ZrH}_{1} .0\right)$ with $8.0 \%$ uranium by weight, 1.47-inch outside diameter, 0.03-inch wall thickness, and a 14-inch fuel column.

\subsection{REACTOR CQRE}

The reactor core consists of standard TRIGA fuel elements (paragraph 5.2) and graphite dummy elements arranged in a standard TRIGA Mark I grid plate. A neutron source is installed in a peripheral grid position.

\subsection{QNIROL AND SAEETY SYSTEM}

The reactor control and safety systern consists of the measuring channels $(3.2 .2)$, safety channels $(3.2 .3)$ and three borated graphite control rods and 
their drive mechanisms. The control rods are positioned remotely to control reactor power and fall into the core by gravity after interruption of magnet current by automatic or manual trips or by loss of console power.

\subsection{REACTOR HALL}

The reactor hall is a confinement structure with a controlled and filtered exhaust.

\subsection{SHIEDING}

The water in the tank provides radiation shielding for all but the collimator area. A high-density concrete shield attenuates to less than 2 $\mathrm{mrem} / \mathrm{hr}$ the fission neutron and gamma flux resulting from absorption of thermal neutrons during fuel pin radiography except for gaps and shield penetrations where leakage necessitates the establishment of local radiation zones during reactor operation. 


\subsection{ADMINISTRAIIYE CONTROLS}

$6.1 \quad$ ORG,ANIZAIION

\section{1 .1 Management}

The Vestinghouse Hanford Company (WHC) Management lines of responsibility for the operation of the Neutron Radiography Facility iNRF) are shown in Figure 6.1.

The President and the Executive Vice-President of WHC have overall responsibility for the operation of WHC. They are advised in the safety aspects of this responsibility by the Safety \& Environmental Advisory Council, a committee of management personnel having extensive know ledge and experfence in various aspects of operational safety. The Council is appointed by and reports to the President of WHC. The duties and responsibilities of this Council are detalled in the FSAR, Section 9.

The President and Executive Vice-President of WHC delegate their operational and safety responsibilities for operations to the Manager of Enginesring anc. revelopment Divisi, ns, which are further delegated to the Manager of Advanced Reactor Lavelopment Division. Responsibilities in the field of reactor fuel fabrication including operation of the NRF TRIGA Reactor are delegated to the Manager, Core Components. The management responsibilities for the operation of the NRF are delegated to the Manager. Fuel Sufply. He delegates the general management, operational and safety responsibilities to the Manager, Faclitty Operations and Administration. Direct supervision of the operation of the reactor is delegated to the Reactor Operations Supervisor (RUS). All of these written delegations of responsibility emphasize siffety and carry adequate delegations of authority to support the assigned respinsibilities. 


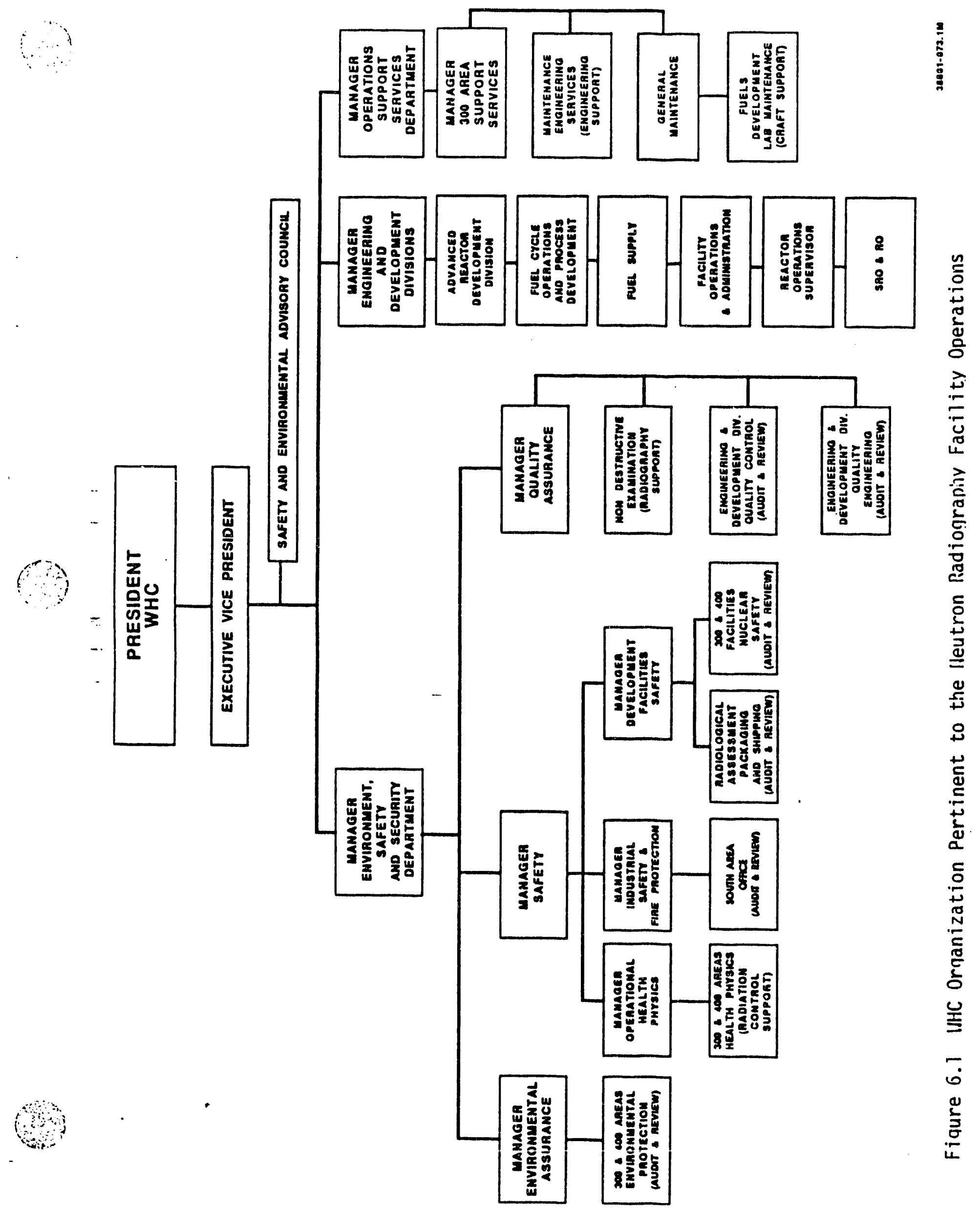




\subsubsection{Eacility Oroanization}

1) The Manager, Facility Operations and Administration is assigned the general management responsibility for the safe operation of the Facility. He shall be a certified Senfor Reactor Operator.

2) The staff reporting to the Manager, Facility Operations and Administration consists of the Reactor Operations Supervisor (ROS), Senfor Reactor Operators (SRO), and Reactor Operators (RO).

3) The qualifications of this staff include a course of training in the operation of the reactor, including recovery from abnormal conditions and emergencies. The qualifications of the ROS and SRO include knowledge of management aspects, such as relationships with user and customer groups within WHC and reporting requirements.

4) The ROS may designate a SRO as his alternate. The designation shal 1 be in writing and shall be approved by the Manager, Facility Operations and Administration. While acting as his alternate, the SRO shall have all the authority of the ROS.

5) The duties of the Reactor Operations staff shall include:

a) Elther the ROS or his alternate shall be present in the control room or the reactor hall to perform or supervise the following operations:

- Any maintenance on a control rod or drive unit.

- Change of core configuration or loading and initial operation after any change of core configuration or loading.

- The first run of any new type or class of experiment. 
b) An SRO shall be present in the control room or reactor hall to perform or supervise the following operations:

- The initial startup of each operating day.

- Any rod worth calibrations.

- Any reactor or reactor equipment testing that requires withdrawal of control rods.

- Precise reactor operation for calibration of instruments, and rod drop time determination.

c) Elther the ROS or his alternate shall be on call at all times when the reactor is not shut down. "On call" shall mean that al 1 of the following conditions can be met:

- The Reactor Operator on duty can contact the ROS by telephone or by radio-pager within 5 minutes if an emergency should arise.

- The ROS can contact the Reactor Operator by telephone with in 10 minutes, if paged.

- The ROS can proceed to the Facllity to arrive within 30 $m$ inutes of the first call or page by the Ro on duty.

d) The ROS is assigned the responsiblilty for review, approval, scheduling and supervision of experiments. The Manager, Facllity Operations and Administration shall review and approve all new experiments.

e) The ROS initiates or approves test plans and special procedures and obtains approval of others as required. 
f) The ROS shall maintain an up-to-date flle of "as-built" drawings showing the current facility status.

g) Minimum staff requirement: During reactor operation, a certified RO or SRO shall be at the console. In addition, at least one other person shall be in the laboratory portion of the 308 Bullding complex while the reactor is operating, and the operator at the console shall have avallable a rapid means of communications with that person.

\subsubsection{Supporting Organizations}

Technical support for the facility operation is provided by Nondestructive Examination and Operational Health Physics. Members of support organizations, while performing service functions for the operation of the facility, shall be under the direct authority of the person supervising reactor operations.

1) Certified neutron radiographers are provided by Nondestructive Examination and/or Facility Operations and Administration. Their duties are to:

a) position the items to be radiographed other than irradiated materials, b) position the film cassette, c) give the reactor operator the desired exposure time, d) remove the items, other than irradiated materials, and the cassette after the exposure, and e) develop and interpret the films. Positioning of all irradiated materials is performed by TRIGA Reactor Operations personnel using approved operating procedures.

2) Maintenance of the Facility is performed, and assistance is given in calibration and testing of the Facility equipment, by laboratory maintenance personnel from 300 Area Support Services. Their duties are detalled in the Maintenance Manual. 
3) Radiation monitoring services are provided by 300/400 Area Health Physics, an organization of Operational Health Physics. The duties of the Radiation Protection Technologists are to assure personnel radiation safety in accordance with the WHC Radiation Protection Procedures.

4) Facility engineering is provided by an engineer from 300 Area Support Services Maintenance Engineering Service Group.

\subsection{AUDIT AND REYIEN}

WHC has established scheduled audits and reviews of facility operations in compliance with DOE Orders 5480.6 and 5482.1B. These audits and reviews provide assurance that facllity procedures and controls are adequate for safe facility operation and that operations are performed in accordance with these procedures and controls. The organizations implementing the audits and reviews are independent of the operating organization to the Executive Vice-President. The organizations performing this function shown in Figure 6.1, and their functions are briefly described below.

\subsubsection{Audit and Review Oroanizations}

\section{1) Reactor Safety}

300/400 Facllitles Nuclear Safety w111 conduct perlodic audits of the facility operation for compliance with internal controls, procedures and Technical Specifications, and an annual appraisal of the effectiveness of these administrative controls. Audits for criticality safety will also be conducted. The duties and responsibilities of $300 / 400$ Facllities Nuclear Safety are detalled in the FSAR, Section 9.

On a routine basis, the following items shall be submitted to 300/400 Facllities Nuclear Safety for revlew: 
- Proposed changes to procedures, equipment or systems having. safety significance.

- Experiment proposals.

- Proposed changes to the Technical Specifications.

- Reports of unusual performance of equipment.

- Reports of violation of DOE regulations, orders, Technical

Specifications or internal procedures and controls.

- Reports of Unusual Occurrences, Critiques, Event Fact Sheets, and incidents.

- Proposed changes to the FSAR and supplements.

\section{2) Qperational Health Physics}

Operational Health Physics will review all proposed new facility operations to evaluate the potential radiation hazards.

3) Radiological Safety and Environmental Protection

Radiological Assessment, Packaging \& Shipping will perform periodic audits of the facility operations to evaluate conformance to WHC requirements for protection of employes. 300/400 Areas Environmental Protection will perform periodic survelliances to evaluate protection of the environment.

\section{4) Industrial Safety and Fire Protection}

Industrial Safety and Fire Protection will conduct pericdic audits of the facility and its operations to assure the maintenance of a high standard of industrial safety.

5) Quality Assurance

Quality Assurance will prepare and maintain the QA program plan for the Neutron Radiography Facility and perform audits, reviews and inspections as required by that plan. 
The Safety \& Environmental Advisory Council is a management committee responsible for review of WHC operational safety. The Council reviews nuclear and radiological design criteria for new facilities and significant changes to existing facilities, safety Analysis Reports, Technical Specifications and changes in operating mode which may increase the probabllity or consequence of an accident. Council approval will be required prior to implementation of any of the above or changes thereto.

\section{7) Other}

Internal criticality safety audits and safety and housekeeping audits will be performed periodically by a 308 Building Laboratory certified Fissionable Material Handler.

Reports of each of the above formal audits and reviews, including recommendations, will be submitted to the appropriate level of management by the auditing group in accordance with the requirements of the individual audit or review programs.

\subsection{OPERATING PROCEDURES}

The Neutron Radiography Facllity including the TRIGA reactor shall be operated in accordance with approved, written procedures. Procedures shall be written for all normal operations, maintenance, anticipated emergency cond 1tions and test or special operations affecting the facility. The specific operations which will be covered by standard procedures include, but may not be 1 imited to:

\footnotetext{
- Reactor startup

- Normal reactor operation

- Reactor shut.down

- Refueling the reactor

- Maintenance
} 
- Normal facility equipment operation (including precautions)

- Alarm response

- Fuel element leak search

- Facility emergencies response

- Radiation control (Radiation Work Procedures)

- Neutron Radiography operations

- Experiments

- Facility Modifications

\subsection{RECORDS AND LOGS}

Facility logs and records will be maintained to provide a complete and accurate history of the TRIGA reactor and its assoclated equipment. Specific records to be maintained, and the minimum period they will be retained are:

- Record of normal reactor operations - 5 years

- Startup and shutdown checkoffs - 5 years

- Radiation and contamination survey record - 5 years

- Fuel element histories - life of the facility

- Reactor power record - 5 years

- Personnel exposure records - indefinitely

- Reports of unusual occurrences - life of the facility

- Records and safety evaluations of procedure changes or equipment alterations - life of the facility

- Record of significant maintenance tests and inspection - life of the facility

- Record of material radiography exposures - life of the facility

- Records of operator training and qualification - life of the facility

- Facility plans and drawings - life of the facility

- Record of radioactivity released to environment - 5 years

- Audit and Appraisals Reports - life of the facility

- Records of facility modifications - life of the facility

- Records of material irradiations - life of the facility 


\subsection{ACTION TO BE TAKEN IN THE EVENT A SAFETY LIMIT IS EXCEEDED}

If a safety limit is exceeded, the following actions will be taken:

- The reactor will be shut down immediately, notify the ROS or his designated al ternate.

- The ROS, or his alternate will inform responsible line management and the Environment, Safety and Security Department. Environment, Safety and Security shall notify the U. S. Department of Energy (DOE).

- The occurrence will be investigated, including analysis of the cause and extent of posstble damage.

- Corrective action will be taken as required, and actions will be taken to prevent or reduce the probability of recurrence.

- Written reportș will be submitted as required in Section 6.8.

- Reactor Operation shall not be resumed until written authorization has been received from DOE.

\subsection{ACTION TO BE TAKEN IN THE EVENT OF AN UNUSUAL OCCURRENCE}

In the event of an unusual occurrence the following actions will be taken:

- Call first Aid, Fire Protection, Patrol and the Environment, Safety and Security Department as necessary to cope with any emergency situation.

- The Reactor Operations Supervisor or his alternate will be notified.

The Reactor Operations Supervisor or his alternate will determine if operations should be suspended immediately. 
- The Reactor Operations Supervisor or his alternate will inform responsible line management and Environment, Safety and Security Department. DOE and other organizations will be informed as dictated by the specific occurrence. The Operating Department Manager shall determine whether the occurrence is reportable to DOE and shall notify DOE if necessary.

- Corrective action will be taken as required, and actions taken to prevent or reduce the probability of recurrence.

- Written reports will be submitted as required in Section 6.8 .

\subsection{ACTION TO BE TAKEN IN THE EVENT OF AN ABNORMAL OCQURRENCE}

In addition to the actions 1 isted for unusual occurrences listed in Section 6.6 the following actions shall be taken.

- The person in charge of the reactor will shut down the reactor if it is operating.

- The reactor may be restarted only with 300/400 Area Facilities Nuclear Safety approval.

\subsection{REPORTING REQUIREMENTS}

In addition to the requirements of applicable DOE Manual Chapters, reports shall be made to DOE as follows:

6.8.1 An immediate report (by telerhone) of:

- Any accidental offsite release of radioactivity above permissibio limits, whether or not the release resulted in property damage, personal injury or exposure.

- Any violation of a safety limit. 


\subsubsection{An Event Fact Sheet will be submitted with in 24 hours of:}

Any event or unusual occurrence as defined in Section 1.2 or 1.3 of these Specifications.

\subsubsection{A written report with in 10 days of:}

Any accidental offsite release of radfoactivity above permissible 11 mits, whether or not the release resulted in property damage, personal injury or exposure.

Any violation of a safety $11 \mathrm{mit}$.

Any unusual occurrences as defined in Section 1.2 of these Specifications.

The results of a Critique as defined in Section 1.4 of these Specifications.

\subsubsection{A written report within 30 days of:}

- Any significant variation of measured values from a corresporiding predicted or prevlously measured value of safety-connected operating characteristics occurring during cperation of the reactor.

- Any significant change in the transient or accident analysis as described in the Final Safety Analysis Report.

- Any significant changes in facility organization or personnel for which minimum qualifications are specified in the Final Safety Analysis Report. 


\subsubsection{A written report with in 60 days:}

- After the initial criticality of the reactor upon receipt of a new facility operating authorization or an amendment authorizing an increase in maximum permissible reactor power level.

- After installation of a new core or major portion thereof. The report shall describe the measured values of the operating parameters or characteristics of the reactor under the new conditions.

6.8.6 A routine written repert with in 60 days after completion of the first calendar year of facility operation and at the end of each 12-month perlod thereafter. The report shall be written by the operating organization and provide the following information (where reports providing the following information are submitted to comply with DOE Manual Chapters or other reporting requirements, duplicate reporting is not required):

1) A narrative summary of operating experience and of changes in the facility design, performance characteristics and operating procedures related to reactor safety occurring during the reporting period.

2) A tabulation showing the energy generated by the reactor and the number of hours the reactor was critical.

3) The number of emergency shutdowns and inadvertent scrams, including the reasons.

4) Discussion of the major maintenance operations (preventive and corrective) performed during the period, including the effect, if any, on the safe operation of the reactor, and the reasons for any corrective maintenance required. 
5) A summary of the nature and amount of radioactive effluents released or discharged to the environs as measured at or prior to the point of the release or discharge from the facility.

6) A description of environmental surveys performed outside the faclitity.

7) A summary of radiation exposures received by facility personnel and $v$ isitors, including the dates and times of any significant exposures, and a summary of the results of radiation and contamination surveys performed with in the facility.

\subsection{GHANGES TO TECHNICAL SPECIEICATIONS}

Changes to these Technical Specifications shall be in accordance with the foll lowing requirements:

1) Proposed changes shall be submitted by the operating organization to $300 / 400$ Area Facilities Nuclear Safety for review and approval.

2) Following review and approval by $300 / 400$ Area Facllities Nuclear Safety, the operating organization shall submit the proposed changes to the Safety \& Environmental Advisory Council for review and approval.

3) Following review and approval by the Safety \& Environmental Advisory Council, the proposed changes will be submitted by WHC Operating Management with the concurrence of 300/400 Area Facilities Nuc?ear Safety to DOE for review and approval.

4) Changes shall be approved by DOE prior to implementation.

5) The Manager, 300/400 Area Facilities Nuclear Safety notifies the operating organization of DOE approval. 
6) The Reactor Operations Supervisor shall transmit the new specifications to the operating staff by verbal and written instructions. All logs, reco.ds or procedures affected by the revised specifications shall be updated or appropriately annotated by the Reactor Operations Supervisor prior to their use during facility uperations.

7) The Manager, $300 / 400$ Area Facilities Nuclear Safety may, at any time impose temporary limits on facility operations, so long as the limits are more restrictive than the Technical specification 1 imits in effect at that time. Such limits may be imposed while a change to the Technical Specifications is being processed or to allow for a temporary condition during which a more restrictive limit is jesirable. The bases for such temporary limits shall be documented in an auditable form. 
The bases statements are brief summaries of information presented to indicate the source or reason for numerical limits in the Technical specifications. The following bases are numbered the same (with the prefix $A$ added) as the section of the Technical Specification which gives the 1 imits.

A2. SAFETY LIMIT AND LIMITING SAEETY SYSTEM SETIING

\section{A2.1 SAFETY LIMII}

The safety limit which restricts the fuel temperature to $550^{\circ} \mathrm{C}$ or 1 ess ensures the integrity of the fuel element cladding. This limit ensures cladding integrity by limiting temperature-induced cladding stress to an insignificant level (see FSAR, Section 5). The $550^{\circ} \mathrm{C}$ temperature is the point at which fuel phase transformation occurs in the aluminum-clad fuel which has a $\mathrm{H} / \mathrm{Zr}$ ratio less than 1.45 resulting in swelling of the fuel and stressing of the cladding. The stainless steel clad fuel is not subject to fuel phase changes since it has a $\mathrm{H} / \mathrm{Zr}$ ratio greater than 1.45 .

A second possible source of fuel cladding stress is the result of dissociation of the hydrogen in the fuel. The analysis of this problem in the FSAR, Section 5, indicates that there is no significant stress due to the dissoclation at $550^{\circ} \mathrm{C}$. The aluminum and stainless steel clad fuel safety limits due to hydrogen pressure are $900^{\circ} \mathrm{C}$ and $1150^{\circ} \mathrm{C}$, respectively.

\section{A2.2 LIMITING SAFETY SYSTEM SETIING}

A limiting safety system setting (LSSS) of $285 \mathrm{~kW}$ gives assurance that the safety limit will not be exceeded. The maximum calculated power level of the TRIGA reactor with a reactivity of $\$ 3.00$ is $625 \mathrm{~kW}$ with a fuel temperature of $320^{\circ} \mathrm{C}$ for the al uminum-clad fuel and $350^{\circ} \mathrm{C}$ for the stainless steelclad fuel. The maximum LSSS of $285 \mathrm{~kW} \mathrm{will} 1 \mathrm{imit}$ the fuel temperature to less than $350^{\circ} \mathrm{C}$, giving assurance that the safety 1 imit w111 not be exceeded even assuning maximum instrument error. 


\section{A3.1.1 Minimum Shutdown Margin}

The $\$ 1.00(-0.72 \% \Delta \mathrm{k} / \mathrm{k})$ minimum shutdown margin requirement gives as surance that the reactor can be made adequately subcritical even in the event that the control rod with the greatest worth becones inoperable. Two or more independent (unlikely) control rod fallures would be required before the reactor could not be made subcritical. Shutdown margin must also consider reactivity effects both normal and during fallure from experiments which are capable of causing positive reactivity insertions. All precautions should be taken to restrict or limit these effects in accordance with the technical specifications 1 imits.

\section{A3.1.2 Reactivity Insertion Rate}

The 17 cents per second $(-0.12 \% \Delta k / k)$ reactivity insertion rate $11 \mathrm{mit}$ gives assurance that the reactor power will be adjusted in a slow and controlled manner. This limit is several orders of magnitude less than the step insertion of $\$ 3.00$ analyzed in Section 10 of the FSAR, which resulted in a safe maximum fuel temperature of $510^{\circ} \mathrm{C}$.

\section{A3.1.3 Core Reactivity}

The core excess reactivity limit precludes the release of radionuclides due to a fuel fallure caused by loss of reactor control. The FSAR analyses of the maximum achievable steady state power (Section 5) and a step insertion (Section 10) of the maximum al lowable core excess reactivity indicate a maximum fuel temperature of $510^{\circ} \mathrm{C}$, which is $40^{\circ} \mathrm{C}$ less than the safety 1 imit. 


\section{A3.2.1 Scram Iime}

A short scram time is desirable to assure that the reactor can be operated in a controlled manner. The limit of 1.5 seconds gives assurance that the scram function is operating properly; however, a short scram time is not essential for safe reactor operation due to the self-regulating nature of the TRIGA fuel.

\section{A3.2.2 Measuring Channels}

Operation of the measuring channels is essential to maintain reactor operation with in all prescribed limits. The measuring channels operation is required for processing reactor power signals from the core instrumentation so that the safoty channels function as designed.

\section{A3.2.3 Safety Channels}

The safety channels provide alarms or scrams which give assurance that the reactor is operated in a safe and controlled manner.

The linear safety channels initiate an automatic scram in the event the reactor power level reaches the LSSS, which gives assurance of fuel cladding integrity.

The perlod channel alarms when the power is rising too fast (a perlod of less than 3 seconds) to assure that the operator has full control of the reactor power level. Perlods greater than 3 seconds assure a slow, controlled increase in the power level.

The pool water temperature alarm assures that fuel element cooling is adequate to insure cladding integrity. The departure from nucleate bolling (DNB) ratio for a power of $250 \mathrm{~kW}$ and a pool temperature of $60^{\circ} \mathrm{C}$ is approximately 5:2. The DNB ratio of 5.2 is an indication that the heat fiux is 
less than $20 \%$ of that required for film boiling. Damage to nuclear instrumentation $\propto c$ curs above $70^{\circ} \mathrm{C}$. Damage to the water treatment resin may $\propto c u r$ above $45^{\circ} \mathrm{C}$.

The fission chamber high voltage monitor al arms if the voltage level drops to $90 \%$ of normal. The accuracy of measuring channels is maintained at voltages above $70 \%$ of normal.

\section{A3.3 RADIATION MONITORING SYSTEMS}

\section{A3.3.1 Reutine Radiation Monitorine Systems}

The radiation monitoring systems warn personnel of above-normal radiation and airborne particulate activity levels in the reactor hall. The alarm levels will be set consistent with the practice of ensuring radiation exposure is kept as low as reasonably achievable (ALARA) and will give assurance that operator and radiography personnel exposure is less than the yearly al lowable limits set by DOE Order 5480.1B, Chapter 11.

The stack samples yield data for historical radioactivity content of the reactor hall air effluent. In addition in the event of an accidental release they can provide release data.

The air monitors provide prompt warning of high concentrations. These air monitors are also supplemented by routine samples and surveys to determine the radiological status of the facility.

The Area Radiation Monitor normal alarm setting is $10 \mathrm{mR} / \mathrm{hr}$. The Air Particulate Monitor (alpha) alarm is normally set at or below 40 MPC hours. The Alr Particulate Monitor (beta-gamma) alarm is normally set at or below 4 MPC hours.

Operation with alrborne concentrations within the TRIGA area affords no threat to the environment. This slightly contaminated alr must pass through HEPA filters which would remove virtually all of the radioactive particles before release to the outside atmosphere. 
A3.3.2 Radiation Monitoring Systems for Neutron Radiography of Irradiated Fuel

The high-range, gamma-sensitive radiation monftor located within the concrete shielded neutron radiography area alarm point w11l be set as 1 ow as reasonable but shall not exceed $3 \mathrm{R} / \mathrm{hr}$. The purpose of the monitor is to provide an interlock which prevents opening of the rolling concrete door or movement of the cask cart when irradiated fuel is in the neutron radiography facility. The $3 \mathrm{R} / \mathrm{hr}$ limit is the practical setting for a radiation instrument having a log response with an upper range of $10^{4} \mathrm{R} / \mathrm{hr}$. The $3 \mathrm{R} / \mathrm{hr}$ limit is with in the range of portable radiation survey instrumentation that is used when the door is opened and therefore is an acceptable limit.

\section{A3.4 ENGINEERED SAFETY FEATURE}

The ventflation system gives assurance that: 1) airborne radioactive particles are flitered out of the air before being exhausted to the environment: and 2) no unfiltered air leaks out of the reactor hall.

Two sets of ventilation equipment and two sources of power will minimize the possibility of a ventilation system fallure. Each set of equipment is capable of maintaining a negative pressure in the reactor hall and filtering eight air changes per hour before exhausting the air to the environment. $A$ roughing filter and two HEPA f11ters (minimum efficiency 99.95\% each) w111 minimize the amount of alrborne particulates exhausted to the environment.

Pressure instruments will monitor air filters, exhaust fans and room air pressure to ensure that the HVAC system is operating properly. Automatic alarms and switching to the secondary fans w111 occur if negative pressure is lost in the reactor hall. 
The auxiliary safety features provide controls which assure safe facility operation. The locks and interlocks assure that conditions are met which could degrade safety if not met.

The magnet power key lock gives assurance that only authorized (certified) personnel can start up the reactor.

The control rod pushbutton interlock prevents withdrawing more than one control rod at the same time to exceed the reactivity insertion limit (3.1.2). See A3.1.2 for the bases.

The shielding door scram interlock gives assurance that if the door is not fully closed the reactor will be shutdown so that no high radiation levels from the reactor will be present around the opening between the door and the rest of the shielding. Another interlock also prevents movement of the cask cart when the shield door is open. In addition, when a high radiation exists with in the shielded enclosure as during the neutron radiography of irradiated fuel, a high-range, gamma-sensitive radiation monitor inside the enclosure in the alarm position prevents the door from being opened. Similarly, the interlock associated with the radiation monitor removes power from the cask cart to prevent its movement while irradiated components are present in the beam stop area, preventing exposure to operating personnel from an unshielded component.

The reactor pool level monitor warns personnel of high or low pool level. The high pool level alarm assures that personnel are aware of possible flooding from the reactor pool. The low level alarm is an indication that shielding by the water has been reduced and above-normal radiation levels may be present.

The "rod withdrawal prohibit" interlock prevents control rod withdrawal unless there is a reactor power (neutron $f l u x$ ) indication. This interlock 
prevents a possible uncontrolled condition where the reactor could be put on a short period while the neutron flux is below the instrumentation threshold.

The manual scram bar allows the operator to quickly shut down the reactor due to any off-standard indication.

Loss of console power de-energizes all control rod magnets to assure that the reactor fails in a safe condition.

The remote scram switch provides the capability to shut down the reactor from a remote location in the event the reactor hall is inaccessible.

A3. 6

\section{REACTOR COOLANT}

Experience has shown that similar purification equipment in use with other TRIGA reactors can easily maintain coolant conductivity levels of less than - five micromhos per centimeter, and that no visible corrosion of fuel clad or - other components will occur if the four-week average conductivity of the - water does not exceed that value.

\section{A3.7 LIMITATION ON EXPERIMENTS}

Conduct of experiments within the limits of the technical specification requirements for experiments and by reference to further administrative con- trol requirements provides a minimum of necessary steps to take to prevent an experiment from causing damage to reactor components and possible subsequent, release of radioactivity, or exposure of personnel or public to radiation by accident.

The basis for the 25 cent limit on experiments is detailed in Safety Analysis Report Supplement No. 1. If uncontrolled this reactivity would result in a maximum power level increase of $42 \mathrm{~kW}$ and a minimum reactor period of 25 seconds. The limit of 5 cents on pneumatic transfer, experiments with 
rotating parts or other oscillatory reactivity insertion mechanisms is based upon a minimum positive period of 230 seconds and a maximum power level increase of $9 \mathrm{~kW}$. A miscalculation of the reactivity worth of these experiments by a significant amount would not lead to reactor damage, significant personnel exposure or exceed the safety 1 imit of $550^{\circ} \mathrm{C}$.

Neutron radlography of irradiated fuel is 1 imited by the radiation and heat rejection capabilities of the transfer cask and shielded enclosure over the reactor. These 1 imits have been established at $5 \times 10^{4}$ curies of total fission product inventory and/or 120 Watts of heat generation, whichever is smaller.

The $5 \times 10^{4}$ curies of total fission product result in a radiation exposure rate of $6 \mathrm{mR} / \mathrm{hr}$ at the surface of the concrete shield beam stop and less than $100 \mathrm{mR} / \mathrm{hr}$ at the surface of the transfer cask. The 120 Watts of heat generation results in a maximum fuel pin temperature of $360^{\circ} \mathrm{F}$, well within the fuel cladding limit of $1500^{\circ} \mathrm{F}$.

Similarly, the surface dose rate at the centerline of the shipping cask shall not exceed $100 \mathrm{mR} / \mathrm{hr}$. This $1 \mathrm{imit}$ provides assurance that irradiated components accepted for neutron radlography will not create excessive exposure rates to operating personnel while being transported in the transfer casks or being neutron radiographed.

Irradiated material accepted for neutron radiography shall be contained in a sealed metal container. This container must satisfactorily pass a standard helium leak test prior to use in the neutron radiography facility. This container provides a barrier for added assurance that gaseous fission products or particulate fuel pin contamination will not contaminate the neutron radiography facility if, for some reasun, the primary containment barrier should fall. 
A4.0 SURVEILLANCE REQUIREMENTS

A4.2.1 Linear Safety Channel Calioration

The annual calibration of the flux measuring safety channels gives assurance that the accuracy is adequate to ensure that the safety 1 imits are not exceeded. The annual calibration perlod is the standard time between calibrations established by experience from over 50 reactor years of TRIGA operation. A channel test prior to each operating period gives assurance that the safety channels and trip settings are operating properly.

\section{A4.3.1 Reactivity Surveillance}

The core excess reactivity limit precludes the release of radionuclides due to a fuel fallure caused by loss of reactor control. The FSAR analyses, of the maximum achievable steady state power (Section 5 ) and a step insertion (Section 10) of the maximum al lowable core excess reactivity, result in a maximum fuel temperature $\left(510^{\circ} \mathrm{C}\right)$ less than the safety 1 imit of $550^{\circ} \mathrm{C}$.

\section{- A4.3.2 Control and Safety System Surveillance}

Surveillance of the control and safety system gives assurance that the reactor control and monitoring system operates as designed. The surveillance consists of both operational tests and calibrations. The surveillance period was established by considering the experience from over 50 reactor years of TRIGA operating using the same type of instrumentation.

\section{A4.3.3 Radiation Monitoring System Surveillance}

The radiation monitoring system survelllance consists of daily observation source tests, and calibrations which gives assurance that the systems operate as designed. The survell lance period was established by considering the instruments and experience at Hanford. 
A4.3.4 Engineered Safety Feature Surveillance

Survellilance of the HVAC system operation gives assurance that the system provides pressure control as designed. It al so assures that the alarms will function to alert operations personnel in the event of a system failure. Perlodic testing of the HEPA filters gives assurance that the filters will serve their design function of preventing release of radloactive particulate material to the environment.

\section{A4.3.5 Auxtllary Safety Feature Surve11lance}

Surveillance of auxiliary safety features consist of semiannual tests which as sure that they perform as designed. The design specified reliable instrumentation, which gives assurance of reliable performance between tests.

\section{A4.3.6 Coolant Cenductivity Surveillance}

Dally measurement and recording of coolant conductivity provides assurance that any changes in coolant conductivity will be promptly roted and investigated. Weekly monitoring during periods when the reactor is not operated provides sufficient information for the determination of long-term average conductivity.

\section{A4.3.7 Experiment Surveillance}

Requirement for every experiment to be reviewed prior to an operation pro$v i d e s$ a control method to ensure operation with in authorized bounds and safety limits.

\section{A4.4 MATERIAL AND EOUIPMENT CONTRQLS}

\section{A4.4.1 Fissile Material imitations}

The storage of TRIGA fuel within the reactor in standard TRIGA fuel storage racks limit the $k_{e f f}$ of the stored fuel to less than 0.8 . Driver and test 
fuel pins associated with the neutron radiography may be used and stored within the NRF in batches not exceeding $45 \%$ of the minimum critical mass number. This limit prevents criticality from resulting should a double batch occur. WHC fissile material limitations are specified by the Criticality Safety Procedures WHAN-M-6. 


\section{DISTRIBUTION LIST}

TRIGA Safety Documents and Procedures Manual Holders

\begin{tabular}{|c|c|c|c|}
\hline $\begin{array}{l}\text { Copy } \\
\text { Ne. }\end{array}$ & Assianed to: & & Address \\
\hline 1 & GL Jones & TRIGA Reactor Operator & $308-L 4-31$ \\
\hline 2 & RL Tomilinson & $\begin{array}{l}\text { Manager, Facility Operations } \\
\text { and Adm inistration }\end{array}$ & $308-\lfloor 4-31$ \\
\hline 3 & JF Perfect & Reactor Operator Supervisor & $308-L 4-31$ \\
\hline 4 & JF Williams & Manager, Fuels Supply & $308-L 4-34$ \\
\hline 5 & $\mathrm{CN} \mathrm{Jackson}$ & Non Destructive Examinations & $306-L 6-36$ \\
\hline 6 & SPARE & & \\
\hline 7 & JN Paglieri & Nuclear FFTF Safety & $4702 / 55-\mathrm{N} 1-72$ \\
\hline 8 & WP Kunkol & $\begin{array}{l}300 / 400 \text { Area Nuclear } \\
\text { Facilities Safety }\end{array}$ & $328 / 208-L 6-59$ \\
\hline 9 & JN Nansen & $\begin{array}{l}\text { Engineering \& Development } \\
\text { Division Quality Engineering }\end{array}$ & $306 E / 275-L 6-35$ \\
\hline 10 & MA Hill & $\begin{array}{l}\text { Engineering \& Development } \\
\text { Division Quality Control }\end{array}$ & $4702 / 14-N 1-71$ \\
\hline 11 & RR Chaney & Facility Engineering & $328 / 214 A-L 6-55$ \\
\hline 12 & GC Owens & $\begin{array}{l}300 / 400 \text { Area Facilities } \\
\text { Nuclear Safety }\end{array}$ & $328 / 210 A-L 6-59$ \\
\hline 13 & DA Brown & DOE (RL) AMO & $F e d / 674-A 6-50$ \\
\hline 14 & RP Carter & DOE/NOS & Fed/633-A6-50 \\
\hline 15 & Document Control & & $3706-A 4-18$ \\
\hline
\end{tabular}



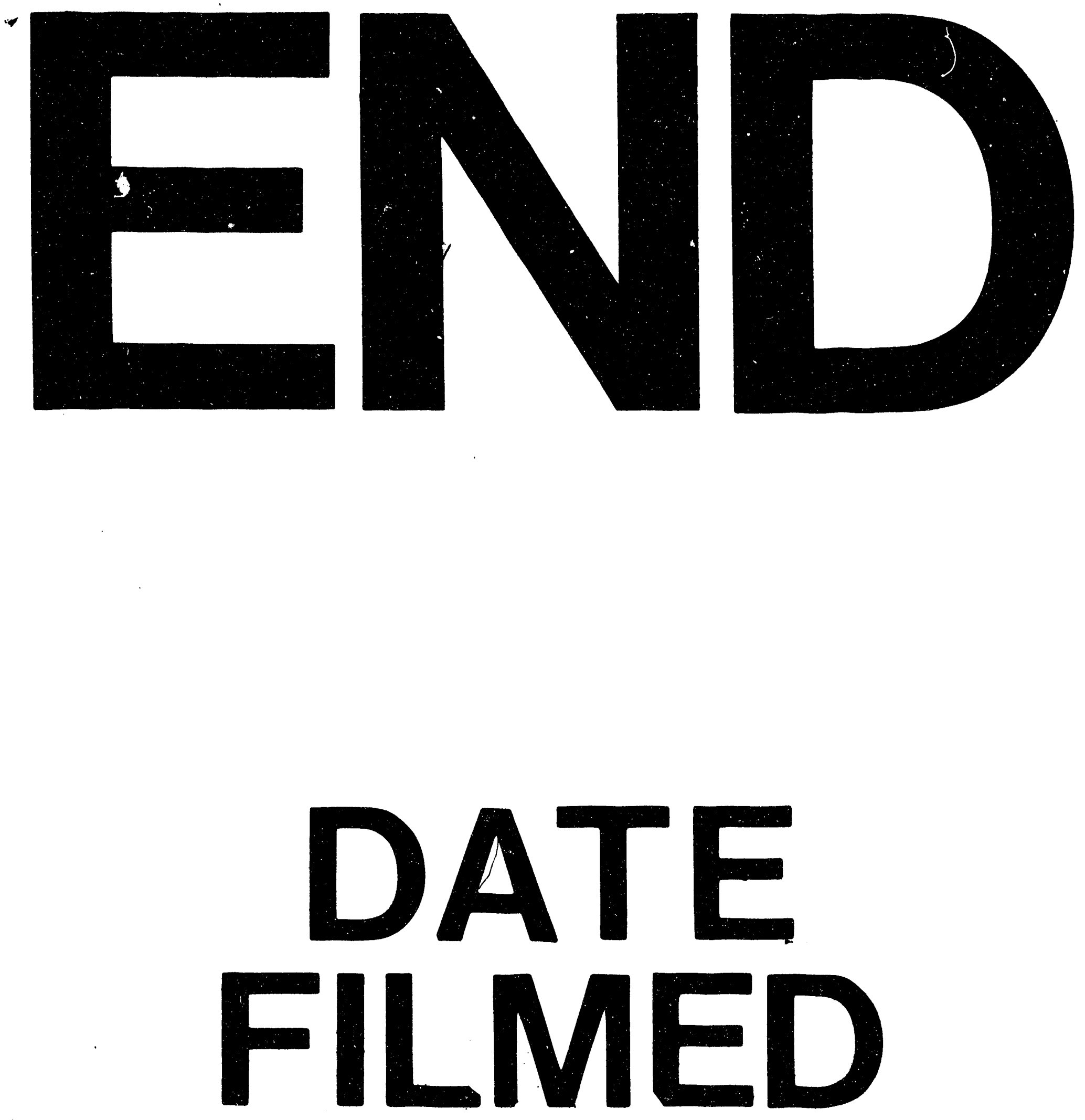

1

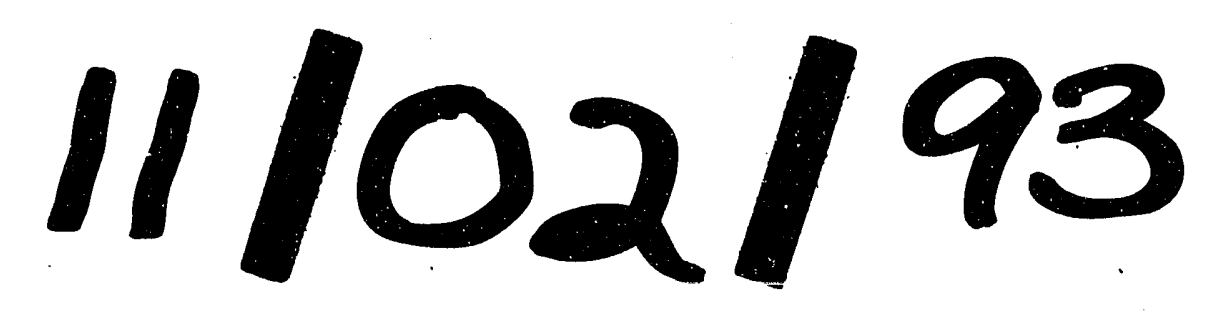

